\title{
How do primary care providers work together in the Iranian PHC system?
}

\author{
Atousa Poursheikhali ${ }^{1}$, Reza Dehnavieh*1 $^{*}$ \\ Received: 17 Jun 2020 \\ Published: 7 Dec 2020
}

\begin{abstract}
Background: Providing coordinated services and forming appropriate cooperation among the members of the health team have a significant impact on other aspects of service provision, including accessibility and continuity of services.

Methods: In this study information was obtained from a national study titled, "Evaluation of Primary Health Care in Iran", and framework analysis was conducted from the perspective of interprofessional cooperation status using the Amour model based on 5 underlying concepts of sharing, partnership, power, interdependency, and process. This is a mixed-method study of the transformative sequential type. In this study triangulation method was used, and data were collected by the Primary Care Evaluation Tool (PCET), interviewing experts and executive directors, and systematic review of the Primary Health Care (PHC) challenges in Iran.

Results: The challenges of the PHC system in Iran are analyzed for providing coordinated care in the form of multidisciplinary teamwork based on the Amour model. The corresponding solutions for improving challenges of the concept are also presented.

Conclusion: Based on the findings of this study the followings are suggested: sharing a collective specialized outlook; designing an integrated information system; improving the educational system through providing on-the-need academic education; strengthening the cooperation of community representatives and people's trustees in providing care; developing interdepartmental partnerships with related organizations with collective interests; moderating the workload of human resources; using electronic health records and automated referral of individuals in addition to appropriate training and promoting the culture from the existing philosophy of primary health care; highlighting the role of service providers as members of the care team; eliminating factors causing instability of suppliers, plans, and programs; and stability in the management approach despite changes in senior management.
\end{abstract}

Keywords: Cooperation, Amour model, Primary health care evaluation, Teamwork, Iran

Conflicts of Interest: None declared

Funding: The study was funded by the WHO office in Tehran (WHO registration: 2015/502280-0).

*This work has been published under CC BY-NC-SA 1.0 license.

Copyright $\subseteq$ Iran University of Medical Sciences

Cite this article as: Poursheikhali A, Dehnavieh R. How do primary care providers work together in the Iranian PHC system? Med J Islam Repub Iran. 2020 (7 Dec);34:164. https://doi.org/10.47176/mjiri.34.164

\section{Introduction}

The decision of the international community to adopt the "primary health care" approach in 1978 led many countries, including Iran, to reform their health care $(1,2)$. The most

Corresponding author:Dr Reza Dehnavieh, r_dehnavi@kmu.ac.ir

1. Health Foresight and Innovation Research Center, Institute for Futures Studies in Health, Kerman University of Medical Sciences, Kerman, Iran important part of the health system and socioeconomic development in each country is primary health care at the community level, and different countries have given priority to its improvement (3). Accordingly, the evaluation of

$\uparrow$ What is "already known" in this topic:

Cooperation of health care providers has attracted much attention in the recent years; and some models and frameworks emphasize different components and functions of this cooperation. Acknowledging the status of each component and function helps to enhance the intragroup and between group cooperation, affecting the quality of the services delivered by health care teams.

\section{$\rightarrow$ What this article adds:}

In this study a comprehensive viewpoint is taken to evaluate the cooperation of care givers by using the Amour model and recommendations are proposed based on the model that tries to respond to all required components, functions, and considerations. 
primary health care plays an important role in its reform process and helps policymakers to lead primary health care towards better achievements $(4,5)$.

According to the model presented by the World Health Organization (WHO), to evaluate how service is provided in a health care provision system, the 4 main dimensions of accessibility, continuity, comprehensiveness, and coordination of services are evaluated (6). Given the importance of primary health care, the coordination of services at this level is an important element in providing appropriate health services. Coordination is one of the most important requirements for the success of a primary care system in each country; and over the last decade, care provided in the form of multidisciplinary and interdisciplinary teamwork has been given widespread attention (7-9). Coordination in health care means providing a coordinated set of care and information that patients require, and it refers to how the provision of services is logically arranged (8).

Multidisciplinary care, such as primary health care, involves the provision of services by those with different specializations who operate under the guidance of a holistic core. This interdisciplinary activity enhances cooperation and relationships and creates a convergent provision of services. In defining the coordination of service provision, service recipients are also considered to be part of the team (10), so their function is effective in enhancing cooperation and coordination among members of the health team. The combination of health teams, mutual understanding of roles, and service providers' same perception of cooperation and group work are the key factors in increasing the effectiveness of provided services to the community (9, $10)$.

According to the Alma-Ata Declaration, the provision of adequate primary health care and compliance with the referral system depend on the human resources in that they should be trained to work as a health team to meet the community's health needs (11). Specialization and focusing on separate professions lead to incoherence in the providers' services, and, as a result, team members will not be able to have a holistic and comprehensive attitude (9). Some studies have found a relationship between the proper teamwork and the quality of service (12). The provision of effective primary health care depends so much on the cooperation of service providers that mature health systems are increasingly focusing on interdisciplinary and multidisciplinary teams for providing primary health care (13-15).

Comprehensive, continuous, and coordinated provision of service as an interdisciplinary and multidisciplinary team is the main way to meet the current and future needs of the population (16). Countries whose primary care systems are sustainable enjoy a better health status at a lower cost (17). One of the main factors behind the achievement of a primary health care system is the use of multidisciplinary and multicarrier teams (18). Such teams can plan to respond to the health and social needs of individuals and provide more coordination for care provision (19).

So far, different models have been presented on improving the cooperation of the providers in the form of working teams. A comprehensive model in which various models were used was presented by Amour et al in 2005. According to this model, there are 5 main components for providing interdisciplinary and multidisciplinary cooperated teamwork, including sharing, cooperation, interdependence, strength, and evolution (10, 20) (Fig. 1).

Sharing includes sharing a common specialized outlook, philosophy of care, values, data, responsibilities, decisionmaking, planning, and interventions among care team members.

The partnership enables 2 or more providers to achieve a set of collective goals (team goals) based on honesty, trust,

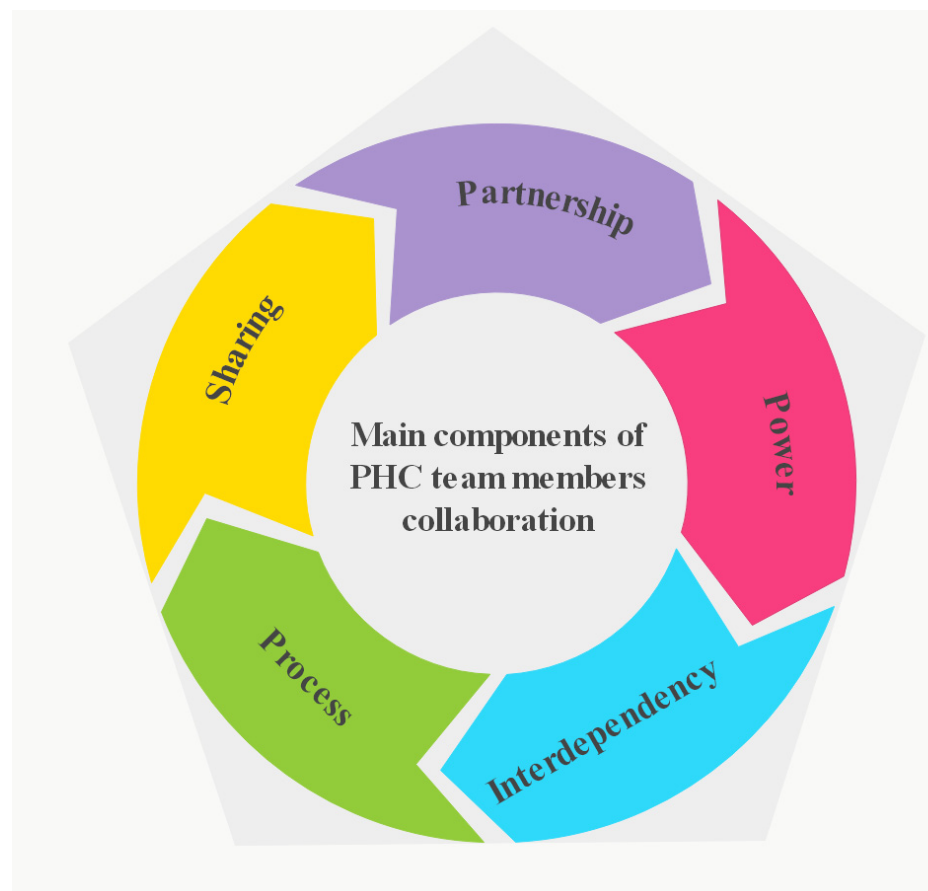

Fig. 1. Main components of the coordinated interdisciplinary and multidisciplinary provision of care, adapted from the model of Amour (10, 20). 
and respect in such a way that each person from each discipline knows and respects the scope and perspective of other group members.

Interdependency indicates the interrelationship between the members of the service providing team and that each person with any specialty and discipline is dependent on others. The formation of cooperation requires experts to be dependent on each other rather than work independently, which results from their collective desire to meet the needs of the recipients.

Power refers to the equal distribution of power among the team members, based on knowledge and experience (not based on the job title or position), with everyone believing in and respecting the power of other team members.

Process refers to the fact that providing coordinated care in cooperation with team members is a process that evolves dynamically over time. The experience of teamwork helps individuals to dynamically correct deficiencies and improve teamwork and coordination.

The purpose of this study is to examine the status of cooperation in the provision of primary health care in Iran. Accordingly, it is important to pay attention to the structure of service provision and the composition of the care team in Iran. The primary health care system in Iran is comprised of 3 levels: health and medical networks, medical sciences universities, and the Ministry of Health and Medical Education (21).

In Iran, the PHC service provider is called the health team, which provides services with a varied combination of members in different health care structures (Fig. 2). This team includes the director of the center, family physicians or general practitioners, family health care experts/professionals, environmental or career health worker/expert, midwives, nurses/Behvarz (Behvarz is the Iranian rural health worker working in health houses), health caregivers, and admissions technicians (22).

The present study is conducted to evaluate the current status of cooperation in Iran's PHC system from the perspective of Amour's 5-construct Model and to identify the challenges in this field.

\section{Methods}

PCET tool: This study is a part of a national project (Evaluation of the Primary Health Care System in Iran). In this national project all aspects of primary health care in Iran have been evaluated based on the Primary Care Evaluation Tool (PCET), developed by the World Health Organization. The tool includes dimensions of service provision, stewardship, financing, and resource generation. In the service provision dimension, this model evaluates the cooperation of service providers, accessibility to services, comprehensiveness, and the continuity of service provision (23). Given that cooperation and coordination are the prerequisites to the achievement of continuity and accessibility to care (14), this study focuses specifically on the results of

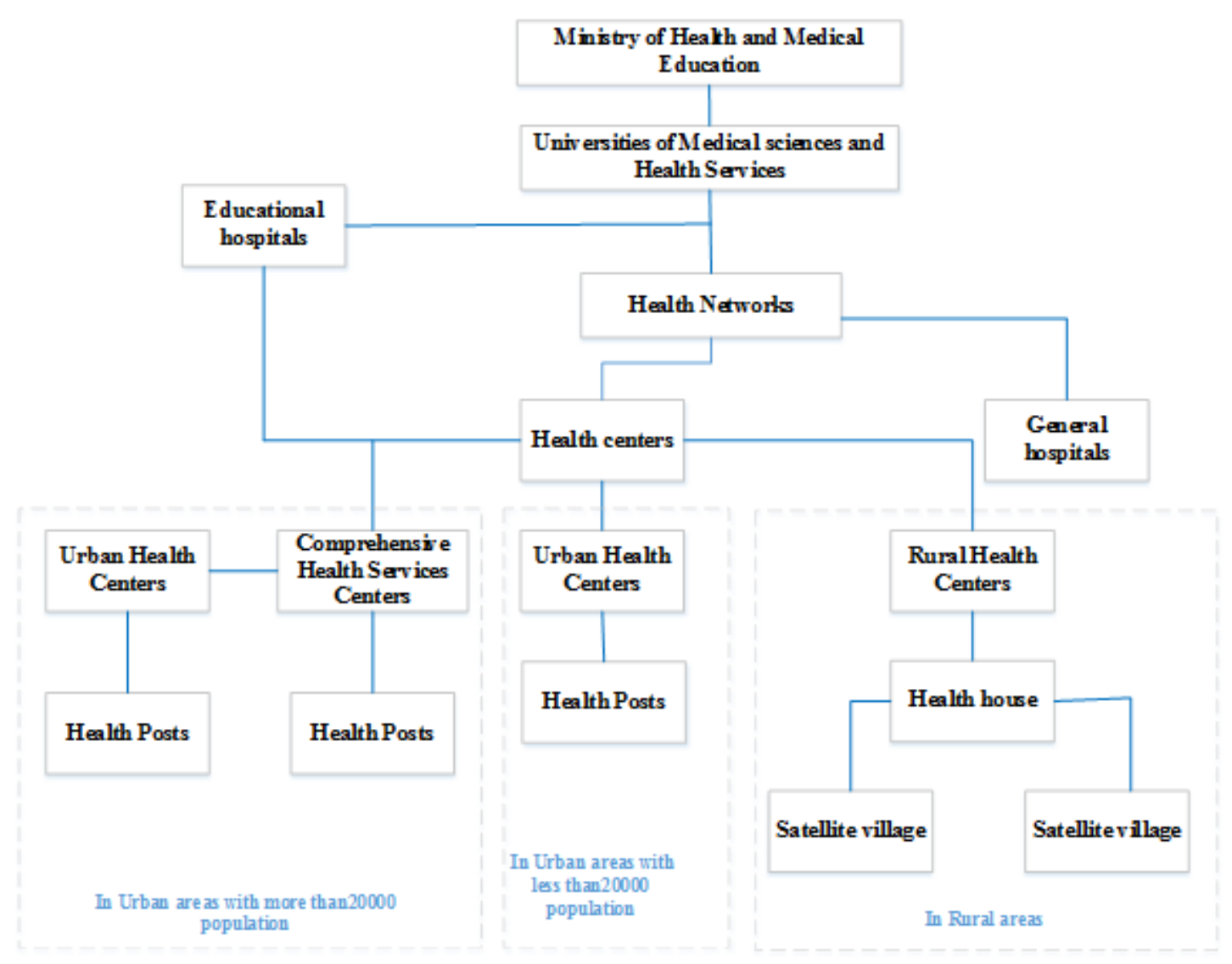

Fig. 2. The health care structure in Iran 
this area. The study is a combined form of sequential transformative method in which quantitative and qualitative data were collected irrespective of the order; then, the data were analyzed (24). In this study, triangulation was used in the methodology. Surveys were performed to identify the volume and magnitude of the related challenges and interviews with experts were conducted to collect their views. Also, challenges of the PHC were studied in Iran through the systematic review of other studies. In this study an analysis of the framework was conducted using the data from 3 phases of the survey, expert interviews, and systematic review using the Amour model. Quantitative data were collected using questionnaires in 5 provinces (Kerman, East Azarbaijan, Khuzestan, Fars, and Mazandaran) of Iran. In the selection of provinces, the geographical location and model of primary health care providers were taken into account. The data gathering tool in this part of the study was a questionnaire of the PCET model, which was customized based on the context of Iran and in 3 main groups of national questionnaires, providers, and recipients of services. The tool was customized with the participation of PHC stakeholders, including service deliverers and policy-makers to ensure the validity of the tool. Also, the alpha Cronbach was 0.87 showing the reliability of the tool. Sampling was done using a multistage classified method. The sample size was estimated to be 4017 according to the guideline for implementing the PCET tool (5 to10 patients per physician and community health workers (Behvarz)). Of this sample size, 200-250 physicians were selected. Also, 5-15 patients were considered for each physician and the questionnaires were distributed in person by the questioner. Finally, 3447 questionnaires were completed by service recipients and 570 were completed by the main providers of services, includ- ing urban and rural family physicians, general medical physicians, and the community health workers (Behvarz). Quantitative data were analyzed using SPSS16 software.

Interview with experts: Subsequently, 30 experts were interviewed about the challenges of cooperation and coordination of health care providers in the primary health care system. The participants were selected purposefully and included network managers and heads of health centers, family physicians, and general practitioners. Interviews were recorded after consent was obtained from the participants. After transcribing the interviews, data were analyzed through content analysis.

Systematic review: A systematic review study was conducted to determine the challenges associated with the primary health care system in Iran. For this purpose, a search was performed in PubMed, Scopus, Google scholar and in Persian databases, including SID, Magiran, and Google scholar, without a time limit using the appropriate combination of the following keywords and their Persian equivalents:

((Primary health care) or (PHC) or (health care) or (health system) or (family physician))

\section{AND}

((challenge) or (limitation) or (weakness))

AND

Iran

The obtained studies were screened in 3 stages (review of title, abstract, and full text). All systematic review steps were separately performed by 2 individuals. Content analysis method was used to analyze the results of the selected articles. The PRISMA diagram of the systematic review study is presented in Figure 3. Also, the papers obtained from the systematic review are presented in the Appendix.

The findings of the 3 methods for analyzing the status of

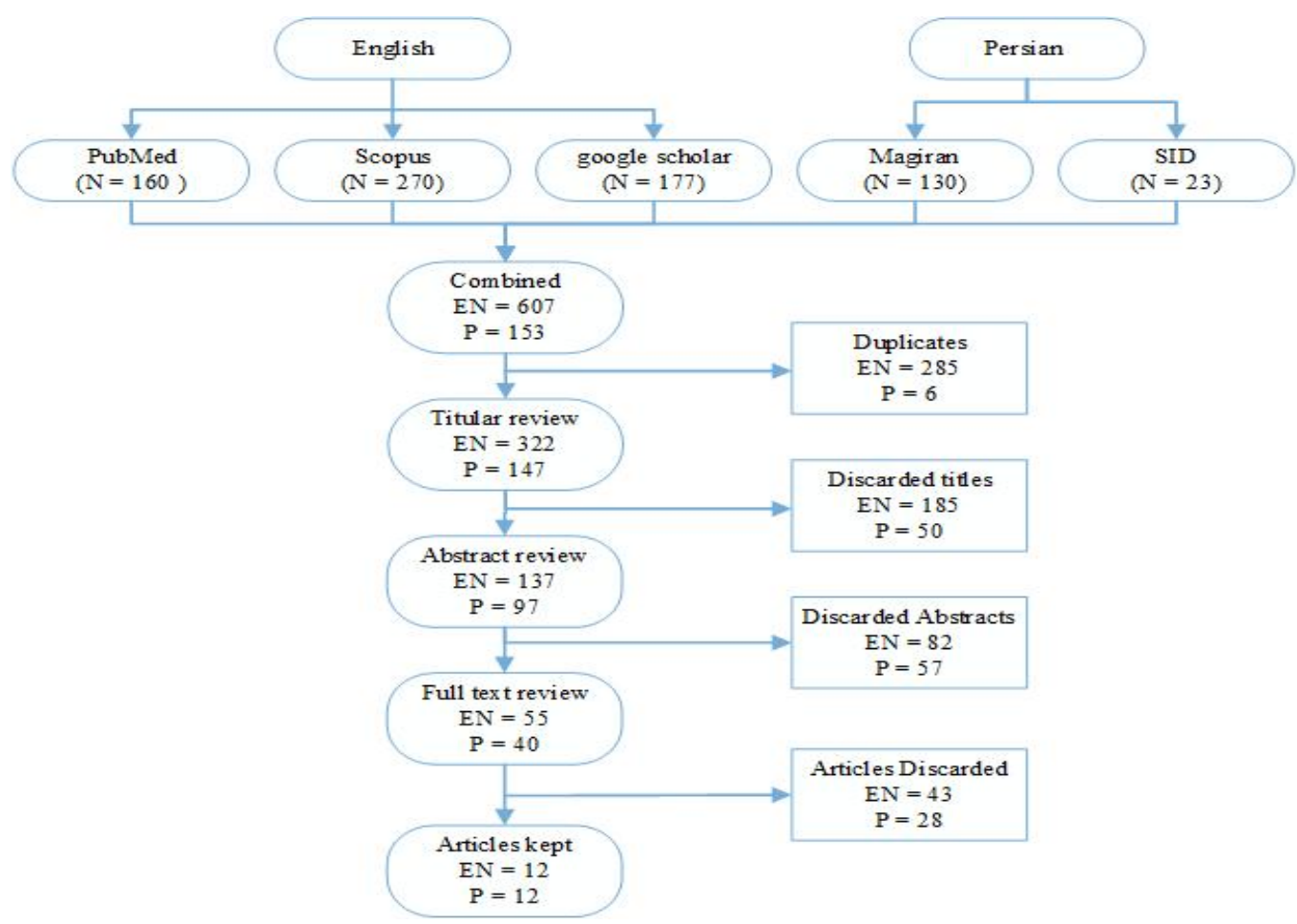

Fig. 3. The PRISMA flow diagram of the systematic review part 
cooperation and coordination of the service provider team were analyzed based on the Amour model of cooperation. The framework analysis conducted from the perspective of interprofessional cooperation was based on 5 concepts of sharing, partnership, power, interdependence, and process. Some recommendations are suggested to improve the cooperation of Iran PHC system cooperation.

\section{Results}

The challenges associated with coordination in the primary health care system of Iran are shown in Table 1. The subcodes have been developed based on the framework analysis of the results derived from the study processes using the Amour model as the based framework.

Example of sharing, as appropriate sharing of these items between providers and recipients of services is helpful in providing coordinated care and strengthening cooperation in the health team.

The lack of a common professional perspective among the caregivers of the health team and the predominantly therapeutic attitude of physicians and other members of the health team are among the challenges of creating cooperation and coordination. Differences in attitude lead to poor interaction between service providers.
"Some family physicians consider themselves in a higher position than other team members and they only deal in treatment (not prevention) process."

Table 2 shows physicians' awareness of the principles of primary health care. More than half of the physicians stated that physicians have limited or moderate knowledge of the issue.

The weakness in informing service providers about new programs and the unintegrated production and dissemination of data will prevent proper data and information sharing. Also, malfunction in the statistics and information system results in inappropriate data sharing.

Some other aspects of sharing data and information are presented in Table 3.

The weakness in the educational system and the lack of community-based training, including academic education, preservice training, and in-service training are among the challenges that affect the level of awareness of family physicians and general practitioners in their duties. The results obtained in this area are presented in Table 4.

Service recipients, as part of the health team, require receiving adequate and essential training. Failure to pay attention to this issue has a great impact on how the referral system is observed.

Table 1. The challenges of cooperation in the primary health care system of Iran, based on the dimensions of the Amour model

\begin{tabular}{|c|c|c|c|c|}
\hline Main Class & Subcode & Article Findings & $\begin{array}{l}\text { Systematic } \\
\text { Review }\end{array}$ & $\begin{array}{l}\text { Inter- } \\
\text { view }\end{array}$ \\
\hline \multirow[t]{8}{*}{ Sharing } & Philosophy of Care & $\begin{array}{l}\text { Focus on treatment (instead of prevention) in some members of the } \\
\text { health team (25) }\end{array}$ & * & $*$ \\
\hline & & $\begin{array}{l}\text { Weak interaction among the team members due to differences in atti- } \\
\text { tudes }\end{array}$ & & $*$ \\
\hline & & $\begin{array}{l}\text { Little attention of physicians of the health team to health issues and } \\
\text { their willingness to refer patients }\end{array}$ & & $*$ \\
\hline & Programs & Poor sharing of new programs (26 and 27) & $*$ & \\
\hline & Data and Information & Unintegrated production and dissemination of data (25) & * & \\
\hline & & $\begin{array}{l}\text { Failure in the system of statistics and information }(25,28,29,30,31 \text {, } \\
32)\end{array}$ & * & \\
\hline & Education & Weakness in the educational system $(33,34,28,25,26,29)$ & * & \\
\hline & & Non-community-based education $(29,35)$ & $*$ & \\
\hline \multirow[t]{2}{*}{ Partnership } & $\begin{array}{l}\text { Inter-departmental Co- } \\
\text { operation }\end{array}$ & Inappropriate interdisciplinary cooperation $(28,25,36,37,38)$ & * & \\
\hline & $\begin{array}{l}\text { Intra-departmental Co- } \\
\text { operation }\end{array}$ & Inappropriate Intradepartmental Cooperation $(39,25,27,38)$ & * & \\
\hline \multirow[t]{5}{*}{ Dependency } & Infrastructure & Heavy workload $(25,40,41)$ & * & $*$ \\
\hline & & Shortage of human resources (42) & $*$ & * \\
\hline & & Poor use of related technologies & & * \\
\hline & Forming the Relation- & Non-observance of the referral chain $(42,26$, and 29$)$ & * & * \\
\hline & ship & Weak cooperation in the implementation of the referral system & & $*$ \\
\hline \multirow[t]{5}{*}{ Power } & Service Providers & $\begin{array}{l}\text { Deficiency in Empowerment, Knowledge, and Skill of the Manpower } \\
\text { ( } 25 \text { and 38) }\end{array}$ & * & \\
\hline & & The Patronizing attitude of some service providers & & * \\
\hline & Service Recipients & Not paying enough attention to empowering people (25) & * & \\
\hline & & The inability of the patient to choose a physician $(26,4,4)$ & * & $*$ \\
\hline & & Service recipients' physician-oriented attitude & & * \\
\hline Evolutionary & Human Resources & Job instability $(39,33,26,36,29,37,41)$ & $*$ & $*$ \\
\hline \multirow[t]{4}{*}{ Process } & & Physicians' and staff's desire to continue education $(25,40,41)$ & * & \\
\hline & Programs & Poor stability of programs & & $*$ \\
\hline & & Lack of proper definition of work processes & & $*$ \\
\hline & & The novelty of some programs & & $*$ \\
\hline
\end{tabular}

Table 2. Physicians' awareness about the principles of primary health care

\begin{tabular}{lccc}
\hline Level of Awareness & Rural Family Physician & Urban Family Physician & General Medical Practitioner \\
\hline Low & $16.6 \%$ & $42.4 \%$ & $16.7 \%$ \\
Moderate & $63.3 \%$ & $22.8 \%$ & $38.9 \%$ \\
High & $20.1 \%$ & $34.8 \%$ & $44.4 \%$ \\
\hline
\end{tabular}




\begin{tabular}{lcc} 
Table 3. Data and Information sharing status & & \\
\hline The Title to be Reviewed & $\begin{array}{c}\text { Behvarz } \\
\text { Pural Family } \\
\text { Physician }\end{array}$ & $\begin{array}{c}\text { Urban Family } \\
\text { Physician }\end{array}$ \\
\hline $\begin{array}{l}\text { Sharing information related to a person referenced to a higher level } \\
\text { Practitioner }\end{array}$ & $\begin{array}{c}\text { General Medical } \\
26 \%\end{array}$ & $\begin{array}{c}23 \% \\
17 \%\end{array}$ \\
$\begin{array}{l}\text { Having the essential information of patients (from the perspective of } \\
\text { patients) }\end{array}$ & - & $3 \% \%$ \\
$\begin{array}{l}\text { The knowledge of the lower level service provision of the results of } \\
\text { the treatment at a higher level }\end{array}$ & $66 \%$ & $59 \%$ \\
\hline
\end{tabular}

Table 4. Physicians' awareness about their duties from their own point of view

\begin{tabular}{lccc}
\hline Level of Awareness & Rural Family Physician & Urban Family Physician & General Medical Practitioner \\
\hline Low & 11.5 & 13.5 & 11.2 \\
Moderate & 52.5 & 23.6 & 72 \\
High & 36 & 62.9 & 16.8 \\
\hline
\end{tabular}

"Most patients see centers exclusively as a place to get the referral letter. It seems when the health team is mostly young, patients won't trust them."

Rural and urban family physicians and general practitioners believe that respectively in $34.5 \%, 54.3 \%$, and $31.8 \%$ of the cases, cultural barriers account for individuals who do not benefit from the care.

\section{Partnership}

Intersectional partnership: Table 5 shows some important aspects related to the status of relationship with the community.

Internal partnership: One of the challenges of interdependency in cooperation was the limited involvement of all stakeholders in decision-making and enacting legislation related to PHC. "Unfortunately, policymaking is done for health behind closed doors." The participation status of family physicians and general practitioners in decisionmaking and policymaking is shown in Table 6.

Among other issues related to intradepartmental cooperation is holding regular meetings between service providers at the first level and between the first and second levels. On average, $20 \%$ of the urban family physicians and $10 \%$ of the general practitioners of the city consult a specialist. Also, 64\% of the community health workers (Behvarz) stated that they consult a family physician in most cases and $71 \%$ of them consult midwives on a monthly basis.

\section{Interdependency}

Infrastructure: Lack of human resources and heavy workload are among the infrastructure challenges in the dependency axis. Failure in completing a task in one part of the care chain due to a high workload causes disruption in providing care.

"The overwhelming majority of organizational posts are non-executive, and there are no recruitment permits."

The lack of proper access to some of the required equipment is another challenge to comply with dependency. The number of equipment items available to physicians, based on at least 44 items of equipment, is presented in Table 7.

Forming the relationship: The development of proper relationships in the primary health care system occurs with the proper formation of the referral system (43). Service providers and recipients need to comply with the referral

Table 5. The status of contact with the community on the provision of primary health care from the perspective of physicians

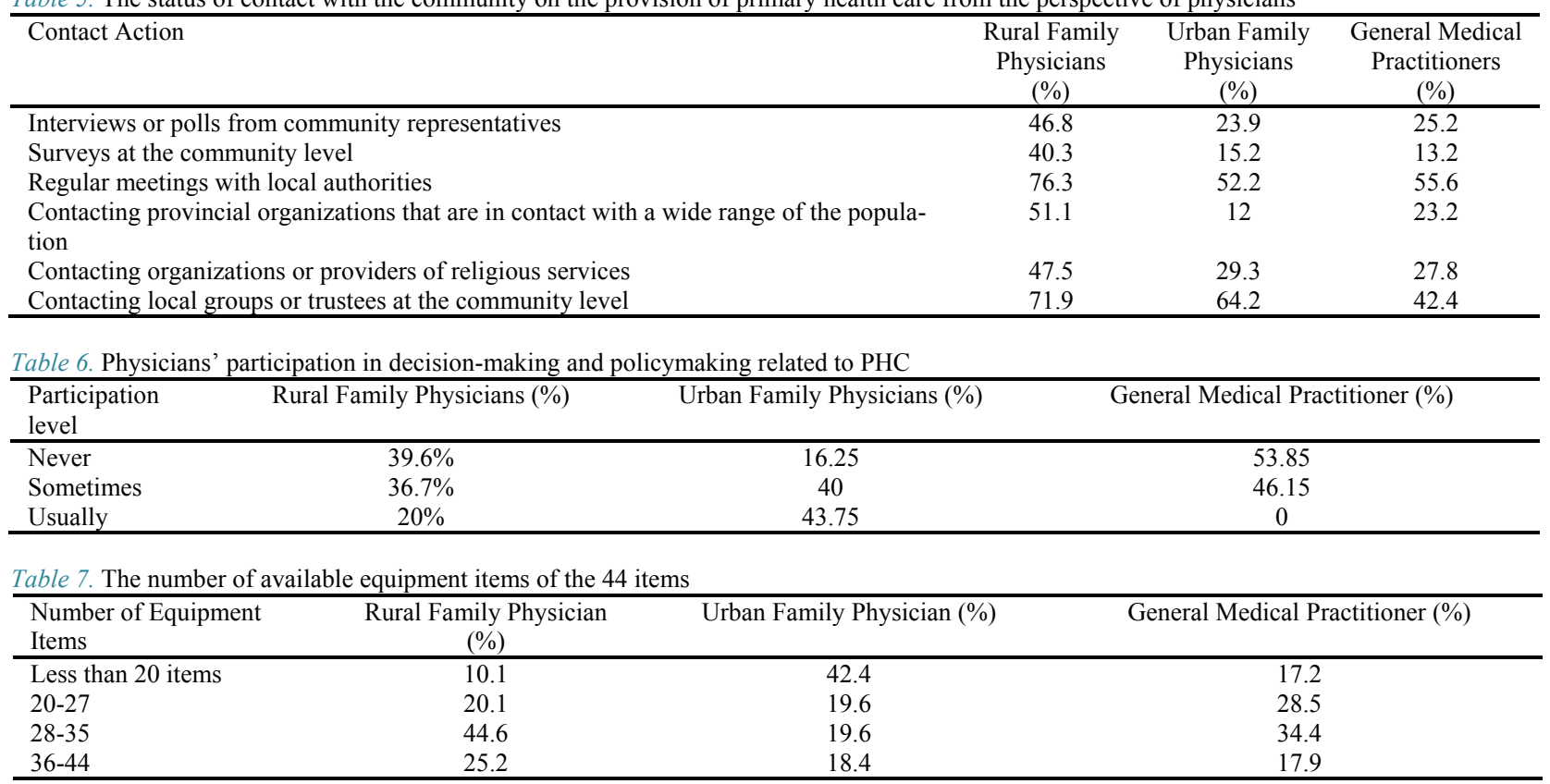


system and there are problems in this regard.

Taking a turn from a higher level of service before referring to the first level of care, referring patients to the first level only for getting the referral form, and individuals' insistence on receiving a referral form are instances of noncompliance of service recipients with the referral system. The results of this study showed $63 \%$ of patients reported they sometimes made an appointment with a specialist prior to visiting a family physician, and $74 \%$ of patients said they would make an appointment with a family physician prior to visiting a community health worker (Behvarz).

Of the community health worker (Behvarz), 43\% said people always refer only for the referral form, while $68 \%$ and $72 \%$ of rural family physicians and urban family physicians stated people sometimes refer only to get the referral form.

Also, $42 \%$ of rural family physicians and $13 \%$ of urban family physicians stated that patients insist on receiving referral forms in unnecessary cases. From the viewpoint of more than $90 \%$ of service providers, patients have a low or moderate awareness of primary health care.

The rate of receiving a feedback from a specialist for all the patients was very low in all 3 categories of rural family physician, urban family physician, and the general medical practitioner, which is another challenge of coordination.

Moreover, $100 \%$ of patients referring to the community health workers (Behvarz) reported that upon asking for a form (in unnecessary cases), the Bahvarz would immediately give them the form, while patients referring to rural and urban family physicians stated that they received the form in $95 \%$ and $58 \%$ of the cases, respectively.

Furthermore, $39 \%$ of urban family physicians and $47 \%$ of rural family physicians stated they do not use referral forms for all referrals.

\section{Manpower}

Service provider: Defects in the appropriate empowerment of the health team result in an unbalanced distribution of manpower among the various providers of service. From the viewpoint of service providers, especially nonmedical providers, this balance is not observed in the team. Also, the hierarchical and patronizing attitude of the members of the health team will lead to imbalance.

Service recipients: Failure to pay enough attention to empowering people as members of the health team is a powerrelated challenge among the recipients of service. For example, $78.45 \%$ of the patients referring to the urban family physicians had chosen their physicians while the rural family physician is assigned to a population and there is no other choice for the people. Also, 52\% of patients referring to rural family physicians do not know whether they can change their family physician. Also, people do not have much knowledge of their rights or principles of primary health care. Table 8 shows the amount of recipients' knowledge about PHC principles from physicians' point of view and mostly in all 3 categories of service delivery (rural, urban, GP), which is low or moderate in rural areas but a little better in urban areas.

\section{Process}

Manpower: Job instability, physicians and staff's willingness to continue education and low stability of manpower and job security are also among the challenges mentioned.

"Physicians stay in the village for a short time, which necessitates manpower, wastes time, and incurs costs." "Unfortunately, assistants are constantly replaced, which causes problems." Also, some service providers mentioned low job security. "We do not know whether our contracts will be renewed for the next year."

Plans and programs: Weakness in the stability of programs and the novelty of the urban family physician plan disrupts the integration of programs. Also, the lack of a collective outlook or a long-term plan will reduce the stability of plans and programs. "Extensive changes in the management system are alarming, and as governments change, the previous programs will also change."

A summary of the solutions suggested in this study to strengthen cooperation in primary health care in the form of interdepartmental teams and multidisciplinary teams are presented in Figure 4.

\section{Discussion}

Providing harmonized primary health care in Iran faces such challenges as the lack of a specialized outlook, the lack of integrated, up-to-date and easy-to-use information system, weaknesses in the training of the care team, failure to take into account the role of service recipients as members of the care team, unbalanced distribution of manpower among members of the care team, low participation of service providers in decision-making and policymaking, weakness in the implementation of the referral system, defect in the evolutionary process of care due to the low stability of programs, low interdepartmental participation, and poor relationship with the representatives of the community and local trustees.

In Iran, health system is integrated with medical education system and medical universities are responsible for both of them. Because of this integration the health providers have a good opportunity to fill the gap between theoretical knowledge \& professional practice (44). The provision of coordinated care requires the establishment of appropriate cooperation between recipients and providers of services, and the role of service providers as members of the

Table 8. Patients' knowledge of the PHC principles from physicians' point of view

\begin{tabular}{lccc}
\hline knowledge & Rural Family Physician (\%) & Urban Family Physician (\%) & General Medical Practitioner (\%) \\
Level & & & 45.7 \\
\hline Low & 75.5 & 46.7 & 55.0 \\
moderate & 22.3 & 7.6 & 44.3 \\
Much & 2.2 & 0.7 & \\
\hline
\end{tabular}




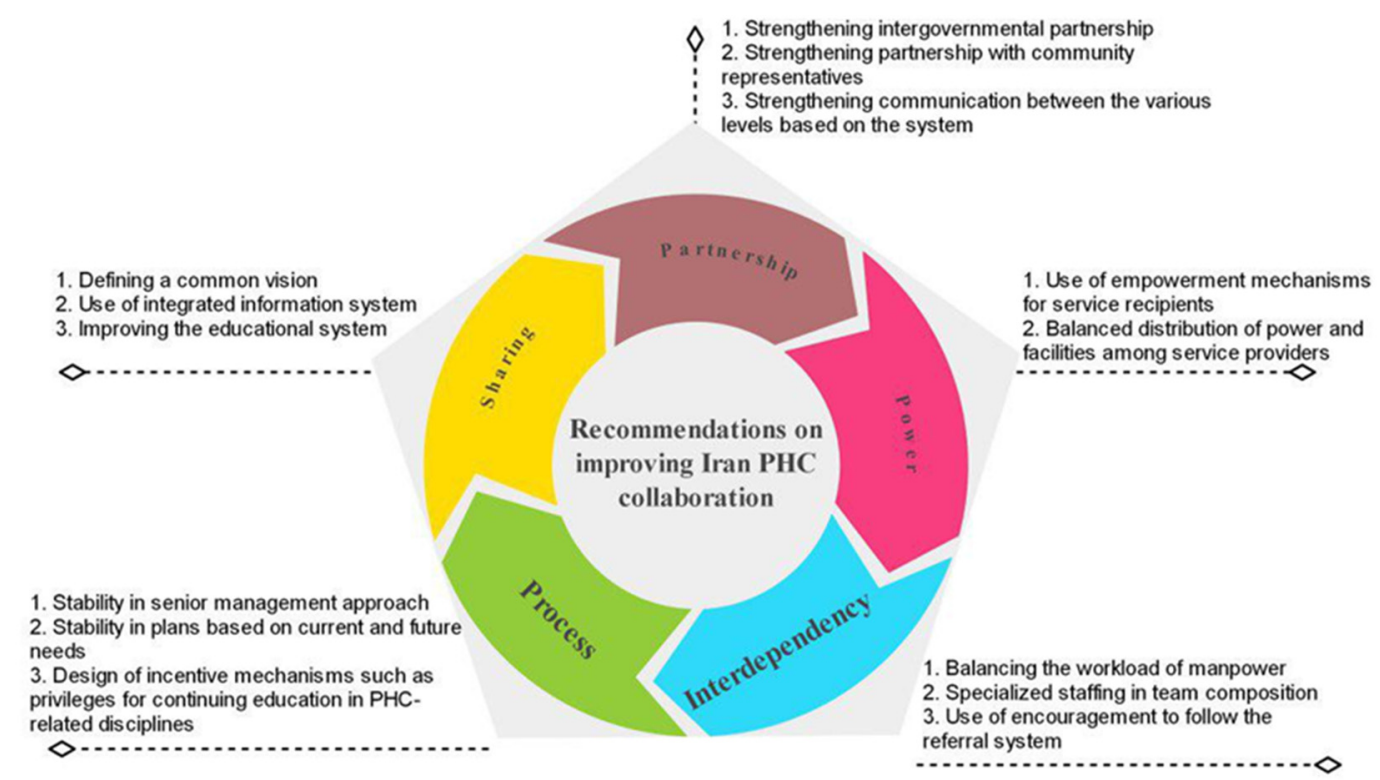

Fig. 4. Recommendations on improving Iran PHC collaboration, based on Amour conceptual model of interprofessional collaboration

care team needs to be seriously considered (7). An important challenge in providing coordinated care is the lack of a collective outlook among service providers and recipients. Differences in providers' attitudes on the one hand and low awareness of service recipients on the other have created some challenges. By defining a collective outlook, the same conception of the philosophy of care is created among the providers and recipients.

Modifying the therapeutic attitude of providers, especially the newly graduated, will have a significant impact on improving coordination among the service provider team. Also, by increasing the general public's awareness about the position of the family physician and the philosophy of health care, their greater cooperation in observing the referral system will be facilitated. In addition to defining the outlook and appropriate training, suitable incentives and punitive mechanisms are necessary for the proper referral of people at different levels of care for both providers and recipients of services (13).

An up-to-date, integrated, and easy-to-use information system is essential to enhance the sharing and exchange of information $(45,46)$; as a result, many of the current challenges, such as family physicians' not being informed of the results of specialist treatment, not sending patient records to specialist physicians, and patients' insistence on receiving referral forms in unnecessary cases will be tackled. As shown in the diagram attached, among the challenges of sharing information in Iran are sending the information of the individual referred to the specialist and the degree of the family physicians' awareness about the specialists' treatment. Based on the obtained results about this challenge, the development of a patient management program is suggested, which includes the use of electronic health records, routing for patients at different levels of care, and training case managers and coordinators in hospitals.

Attracting increased community support will be possible by cementing the relationship with local groups, organizations, representatives, and local authorities (9). To strengthen intradepartmental cooperation, it is necessary to see the process of participation of service providers in decision-making and policymaking as an implementation layer (6).

Organizing regular and targeted joint meetings with different providers, including family physicians, community health workers (Behvarz), caregivers, midwives, experts, and other staff will help share experiences, information, and knowledge, and resolve collaborative challenges. To increase the effectiveness of these meetings and to make them more purposeful, sharing professional experiences and methods of improving the quality of service should be prioritized and meetings should be held between different providers of PHC. Although Iran's public sector share of total health expenditure is lower than the average of the middle-income countries (47), study of technical efficiency in health production showed Iran ranked 12th in terms of the efficiency score among the 36 middle-income countries (48). Comparisons of the results of the evaluation of the meetings of Iranian service providers with other countries using the PCET assessment tool are presented in the attached graph (Graph 1).

Another challenge for primary health care is the shortage of manpower $(49,50)$. Because roles and tasks complement each other in the health team, weakness in one role creates a malfunction in the others.

The other challenge to the proper cooperation of the service team is the failure to comply with the referral system. Different tasks in different levels of service delivery have a high interdependency that can be coordinated through the referral system $(22,7)$. Factors affecting noncompliance can be divided into 2 broad categories of problems caused by community functioning and problems caused by the performance of service providers. In the context of problems caused by the functioning of the community, factors such 


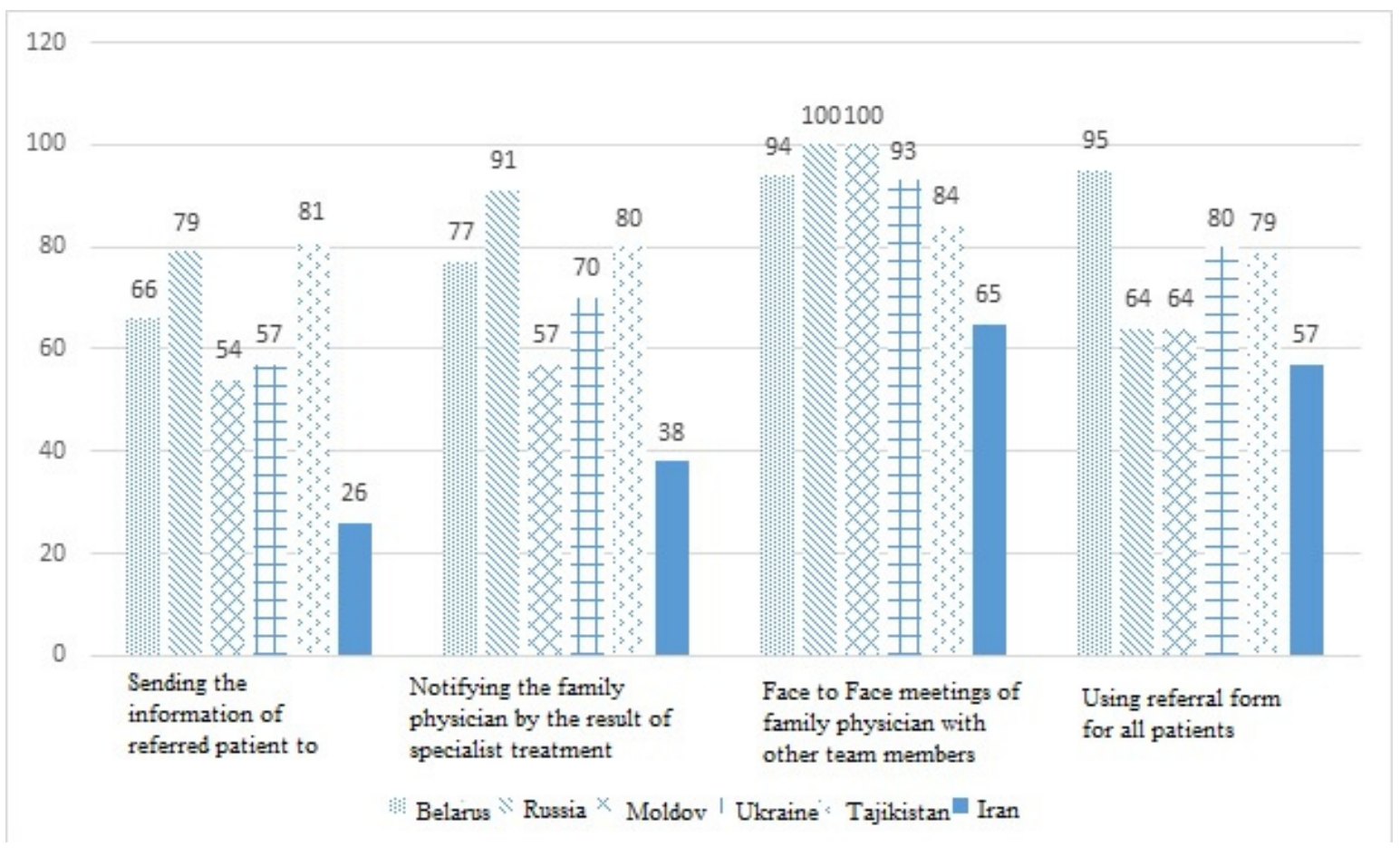

Graph 1. The comparison of some of the aspects of service provision in various countries based on the PCET Model (53-57)

mistrusting family physicians and general practitioners and misconceptions about specialization lead to a lack of proper observance of the referral system on part of recipients of services. Results of a health care utilization study in Tehran showed some people merely seek the form or stamp of referral, and they insist on getting a form or receiving unnecessary diagnostic services (51). Moreover, other problems, including failure to refer patients from the health houses to the health centers, omission of health houses from the referral system, admission of patients without referral at high levels of service, physicians' little attention to health issues at the first level, and the desire of some physicians to refer patients instead of engaging in the treatment process, can be mentioned.

Another challenge for the health teams' coordination in Iran is the lack of proper distribution of manpower among health team members, including recipients and providers of services, which prevents the development of appropriate relationships among the team members (52). The patients' right to choose the physician will make them more collaborative with the PHC system, and elimination of patronizing and top-down relationships in the service provider team can also help to strengthen cooperation and coordination.

Challenges associated with the evolutionary process of providing care are categorized into 2 main groups of manpower and plans and programs. Mechanisms to strengthen the process of cooperation, such as incentive mechanisms for the stability of physicians, support for the progress of service providers in the form of a health team, such as the recruitment of specialized physicians who were initially GPs into the care team, paying attention to the status and rights of service providers, promoting the necessary culture of the position of the care team in the community, and adopting a unified approach to plans and programs can be helpful.

\section{Conclusion}

Because of the increasing complexity of needs in primary health care and ever-increasing specialization, providing care in the form of multidisciplinary teams with different specializations seems necessary. Therefore, various specialists must work together in a team. To achieve this, considering the role of the recipient as a member of the care team is of high importance. There are several challenges in the provision of cooperative care in primary health care teams, including sharing the specialized outlook, plans, data, and information, how the team members participate in chain dependency of tasks and results, and the need for balanced distribution of health manpower and empowerment mechanisms for team members. In addition, eliminating the instability factors in providing care is essential to increase the stability of the programs and to improve management approaches and manpower stability.

\section{Acknowledgment}

We would like to show our gratitude to the WHO office in Tehran.

\section{Conflict of Interests}

The authors declare that they have no competing interests. 


\section{References}

1. Muldoon LK, Hogg WE, Levitt M. Primary care (PC) and primary health care (PHC): what is the difference? Can J Public Health. 2006 Sep 1:409-11.

2. Asadi-Lari M, Sayyari AA, Akbari ME, Gray D. Public health improvement in Iran-lessons from the last 20 years. Public Health. 2004 Sep 30;118(6):395-402.

3. WHO Regional Committee for Europe resolution EUR/RC55/R8 on strengthening health systems as a continuation of the WHO Regional Office for Europe's Country Strategy "Matching services to new needs". Copenhagen, WHO Regional Office for Europe, 2005 (http://www.euro.who.int/Governance/resolutions/2005/20050920_2).

4. Smith, PC, Mossialos E, Papanicolas I. Performance measurement for health system improvement: experiences, challenges and prospects. Copenhagen, WHO Regional Office for Europe, 2008 (http://www.euro.who.int/document/hsm/2 hsc08 ebd2.pdf).

5. Fracolli LA, Gomes MF, Nabão FR, Santos MS, Cappellini VK, Almeida AC. Primary health care assessment tools: a literature review and metasynthesis. Cien Saude Colet. 2014 Dec;19(12):4851-60.

6. Primary Care Evaluation Tool. http://www.euro.who.int/_data/assets/pdf_file/0004/107851/Primary CareEvalTool.pdf

7. Boerma WGW. Coordination and integration in European primary care. In: Saltman RB, Rico A, Boerma WGW, eds. Primary care in the driver's seat? Organizational reform in European primary care. Maidenhead, Open University Press, 2006 (http://www.euro.who.int/Document/ E87932_chapt1.pdf).

8. [17-Measurement of Primary Care- The Johns Hopkins Primary Care ; Position: 12: 613-12: 1244; Author: Atousa; 5/31/2016 9:38 PM; Weight score: 0$]$

9. Xyrichis A, Lowton K. What fosters or prevents interprofessional teamworking in primary and community care? A literature review. Int J Nurs Stud. 2008 Jan 31;45(1):140-53.

10. Chan BC, Perkins D, Wan Q, Zwar N, Daniel C, Crookes P, et al. Team-link project team. Finding common ground? Evaluating an intervention to improve teamwork among primary health-care professionals. Int J Qual Health Care. 2010 Oct 17;22(6):519-24.

11. Solheim K, McElmurry BJ, Kim MJ. Multidisciplinary teamwork in US primary health care. Soc Sci Med. 2007 Aug 31;65(3):622-34.

12. Foronda $\mathrm{C}$, MacWilliams $\mathrm{B}$, McArthur $\mathrm{E}$. Interprofessional communication in healthcare: An integrative review. Nurse education in practice. $2016 \mathrm{Jul}$ 31;19:36-40.

13. Nancarrow SA, Booth A, Ariss S, Smith T, Enderby P, Roots A. Ten principles of good interdisciplinary team work. Hum Resour Health. 2013 May 10;11(1):19.

14. Saltman R, Bankauskaite V, Vrangbaek K. Primary care in the driver's seat?: Organizational reform in European primary care. McGraw-Hill Education (UK); 2005 Dec 1.

15. Virani $T$. Interprofessional collaborative teams. Canadian Health Services Research Foundation; 2012.

16. Wranik WD, Hayden JA, Price S, Parker RM, Haydt SM, Edwards $\mathrm{JM}$, et al. How best to structure interdisciplinary primary care teams: the study protocol for a systematic review with narrative framework synthesis. Syst Rev. 2016 Oct 4;5(1):170.

17. Dinh $\mathrm{T}$. Improving Primary Health Care Through Cooperation: Briefing 2-Barriers to Successful Interprofessional Teams. Can Alli Sustain Health. 2012.

18. Jacobson PM. Evidence synthesis for the effectiveness of interprofessional teams in primary care. Can. Health ser Re Foun; 2012.

19. Goldman J, Meuser J, Rogers J, Lawrie L, Reeves S. Interprofessional cooperation in family health teams. Can Fam Physic. 2010 Oct $1 ; 56(10):$ e368-74.

20. D'Amour D, Ferrada-Videla M, San Martin Rodriguez L, Beaulieu MD. The conceptual basis for interprofessional cooperation: core concepts and theoretical frameworks. J Interprof Care. 2005 May $1 ; 19$ (sup1):116-31.

21. Health system profile, Islamic republic of Iran, 2006. Regional health system observatory, world health organization. Available from URL: http://www.who.int.

22. Ministry of Health and Medical Education. Security and upgrading of primary health care in the form of expanding and strengthening the health network in urban areas. Operating instructions Security and upgrading of primary health care in urban areas and marginal Nshynversion 2. Available from http://www.phc.umsu.ac.ir/uploads/ instruction.pdf.
23. World Health Organization. Systems/primary-health-care publications/2010/primary-care-evaluation-tool-pcet. Primary Care Evaluation Tool. [database on the Internet] [Online]. 9April, 2016. http://www.euro.who.int/en/health-topics/Health

24. Creswell JW. Research design:Qualitative, quantitative, and mixed methods approaches: Sage publications; 2013; 268.

25. Damari B. Challenges and directions of public health development in Iran from the viewpoint of provincial health deputies and health center. Sci J Sch Public Health. 2015;13(1):1- 16. [In Persian]

26. Jabari A, Sharifirad Gh, Shokri A, Bahmanziari N, Kordi A. Overview of the Performance of Rural Family Physician in Iran. Health Inf Manag J. 2013;9(7):1145. [In Persian]

27. Eskandari M, Abbaszadeh A, Borhani F. Barriers of Referral System to Health Care Provision in Rural Societies in Iran. Int J Caring Sci. 2013;2 (3):229-236.

28. Malekafzali H. Primary Health case in Islamic Republic of Iran. Sci J Sch Public Health. 2014;12(2):1. [In Persian]

29. Mehrolhassani MH, Jafari Sirizi M, Poorhoseini S, Yazdi Feyzabadi V. The Challenges of Implementing Family Physician and Rural Insurance Policies in Kerman Province, Iran: A Qualitative Study. J Health Dev. 2012;1(3):193-206. [In Persian]

30. Ramezanian M, Abolhalaj M, Bastani P, Fazl Hashemi S.E, Hamidi H. Islamic Republic of Iran Health System Financing: Weak and Strength Points with a Qualitative Attitude. World J Med Sci. 2013;8(3):231-237.

31. Bagheri Lankarani K, Alavian SM, Peymani P. Health in the Islamic Republic of Iran, challenges and progresses. Med J Islam Repub Iran. 2013;27(1):42-49.

32. Yazdi-Feyzabadi V, Emami M, Mehrolhassani MH. Health information system in primary health care: the challenges and barriers from local providers' perspective of an area in Iran. Int J Prev Med. 2015;6.

33. Jannati A, Maleki MR, Gholizade M, Narimani MR, Vakeli S. Assessing the Strengths \& Weaknesses of Family Physician Program. J Knowl Health. 2010;4(4):38-43. [In Persian]

34. Javanbakht M. Comparative Comparison of Family Physician System in Iran and Other Countries and Study of Family Physician's Problems. J Res Med Sci. 2011. [In Persian]

35. Rajabi F, Esmailzadeh $\mathrm{H}$, Rostamigooran N, Majdzadeh R, Doshmangir L. Future of Health Care Delivery in Iran, Opportunities and Threats. Iran J Public Health. 2013;42(1):23-30.

36. Sedighi S, Amini M, Pourreza A. The reasons of Withdrawing of Physicians from the rural Family Physician Plan. J Isfahan Med System. 2011;5(4):43-33. [In Persian]

37. Asadi S. Family physician Assessment implementation based on the model (SWOT) in Iran. J Med Educ Develop Qazvin Univ Med Sci. 2013;6(2):72-77. [In Persian]

38. Vosoogh Moghaddam A, Damari B, Alikhani S, Salarianzedeh MH, Rostamigooran N, Delavari A, et al. Health in the 5th 5-years Development Plan of Iran: Main Challenges, General Policies and Strategies. Iran J Public Health. 2013;42(1):42-49.

39. Bayati A, Ghanbari F, Hosseini SSh, Maleki A, Shamsi M. Factors Influencing Family Physician Program from the Perspective of the Health Team. J Mazandaran Univ Med Sci. 2014;24(115):22-35. [In Persian]

40. Khalafi A, Shirkhani B, Ghiasi A, Pourreeza A. In-Field Survey of Attractions and Repulsions of Family Medicine: Family Physicians' and Medical Students' Attitudes. J Med Sci. 2013;1(1):51-59. [In Persian]

41. Amiresmaili M, Khosravi S, Yazdi Feyzabadi V. Factors Affecting Leave out of General Practitioners from Rural Family Physician Program: A Case of Kerman, Iran. Int J Prev Med. 2014;5:1314-23.

42. Damari B. Challenges and directions of public health development in Iran from the viewpoint of provincial health deputies and health center. Sci J Sch Public Health. 2015;13(1):1-16.

43. Fracolli LA, Gomes MF, Nabão FR, Santos MS, Cappellini VK, Almeida AC. Primary health care assessment tools: a literature review and metasynthesis. Cien Saude Colet. 2014 Dec;19(12):4851-60.

44. Turani S, Haghdoost AA, Maleki MR, Ravaghi H, Tijang RD, Hekmat $\mathrm{SN}$. The Backgrounds, consequences, and future of the integration of Medical Education and Health Service Delivery System.

45. Ahmadi M, Mohammadi A, Chraghbaigi R, Fathi T, Baghini MS. Developing a minimum data set of the information management system for orthopedic injuries in iran. Iranian Red Crescent Medical Journal. $2014 \mathrm{Jul} ; 16(7)$. 
46. Jafari M, Bastani P, Ibrahimipour H, Dehnavieh R. Attitude of health information system managers and officials of the hospitals regarding the role of information technology in reengineering the business procedures: A qualitative study. Health Med. 2012 Jan 1;6(1):208-15.

47. Sajadi HS, Goodarzi Z, Takian A, Mohamadi E, Olyaeemanesh A, Lotfi FH, et al. Assessing the Efficiency of Iran Health System in Making Progress Towards Universal Health Coverage: A Comparative Panel Data Analysis. Cost Eff Resour Alloc. 29 Jun 2020;18:20.

48. Mohamadi E, Manesh AO, Takian A, Majdzadeh R, Lotfi FH, Sharafi $\mathrm{H}$, et al. Technical efficiency in health production: A comparison between Iran and other upper middle-income countries. Health Policy Technol. 2020 Sep 1;9(3):335-47.

49. Bazyar M, Rashidian A, Jahanmehr N, Behzadi F, Moghri J, Doshmangir L. Prohibiting physicians' dual practice in Iran: Policy options for implementation. Int J Health Plan Manag. 2018 Jul;33(3):e711-20.

50. Bazyar M, Noori Hekmat S, Rafiei S, Mirzaei A, Otaghi M, Khorshidi A, et al. Supply-and-demand projections for the health workforce at a provincial level from 2015 to 2025 in Ilam, Iran. Proceed Singapore Healthc. 2020:2010105820943239.

51. Motlagh SN, Sabermahani A, Hadian M, Lari MA, Mahdavi MR, Gorji HA. Factors affecting health care utilization in Tehran. Glob J Health Sci. 2015 Nov;7(6):240.

52. Noori Hekmat S, Hashemi H, Haghdoost AA, Haji Aghajani M, Janbabaee GH, Maher A, et al. Specialized and geographic distribution of specialists in Iran in 2016 and its estimates in 2026. Iran J Epidemiol. 2018 Mar 10;13:122-32

53. Evaluation of structure and provision of primary care in TAJIKISTAN. A survey-based project. world Health Organization. Available from http://www.euro.who.int/_data/assets/pdf. Oct 2014.

54. Evaluation of structure and provision of primary care in Ukraine. A survey-based project in the regions of Kiev and Vinnitsa. world Health Organization. Available from http://www.euro.who.int/en/countries/ ukraine/publications3/evaluation. 8nov 2016.

55. Evaluation of the organization and provision of primary care in BELARUS. A survey-based project in the regions of Minsk and Vitebsk. world Health Organization. Available from http://www.euro.who.int/. 8nov2016.

56. Evaluation of the organizational model of primary care in the Russian federation. A survey-based pilot project in two rayons of Moscow oblast. Available from http://www.euro.who.int/ data/assets/pdf_file/0008/100250/E92468.pdf.

57. Evaluation of the organizational model of primary care in the republic of Moldova. A survey-based project. Available from https://www.nivel.nl/sites/default/files/bestanden/Rapport-WHOMoldavie.pdf. 
Appendix. Specifications of the selected studies on PHC-related challenges in Iran

\begin{tabular}{|c|c|c|}
\hline Authors (year) & Tittle of studies & Type and methods of studies \\
\hline $\begin{array}{l}\text { Eskandari M, et } \\
\text { al. }(2011-12)(16)\end{array}$ & Barriers of referral system to health care provision in rural societies in Iran & $\begin{array}{l}\text { Qualitative / semi-structured interviews and } \\
\text { small focus group discussions }\end{array}$ \\
\hline $\begin{array}{l}\text { Esmaeili R et al. } \\
(2014)(10)\end{array}$ & Family medicine in Iran: facing the health system challenges & Qualitative / semi-structured interviews \\
\hline $\begin{array}{l}\text { Nasiripour A.A et } \\
\text { al. (2009) (17) }\end{array}$ & $\begin{array}{l}\text { A comparative study of primary health care management in selected coun- } \\
\text { tries and designing a model for Iran }\end{array}$ & Qualitative / triangulation \\
\hline $\begin{array}{l}\text { Malekafzali H } \\
(2009)(18)\end{array}$ & Primary health care in the rural area of the Islamic republic of Iran & - \\
\hline $\begin{array}{l}\text { Amiresmaili M.R } \\
\text { et al. (2011) (19) }\end{array}$ & $\begin{array}{l}\text { Factors affecting leave out of general practitioners from rural family physi- } \\
\text { cian program: a case of Kerman, Iran }\end{array}$ & Cross-sectional / questionnaire \\
\hline $\begin{array}{l}\text { Rajabi F et al. } \\
(2013)(20)\end{array}$ & Future of health care delivery in Iran, opportunities and threats & $\begin{array}{l}\text { Qualitative study / focus group discussions and } \\
\text { semi-structured in-depth interviews }\end{array}$ \\
\hline $\begin{array}{l}\text { Sheikhattari P et } \\
\text { al. (2010) (21) }\end{array}$ & $\begin{array}{l}\text { How can primary health care system and community-based participatory } \\
\text { research be complementary? }\end{array}$ & Review article \\
\hline $\begin{array}{l}\text { Ramezanian M et } \\
\text { al. (2011) (22) }\end{array}$ & $\begin{array}{l}\text { Islamic republic of Iran health system financing: weak and strength points } \\
\text { with a qualitative attitude }\end{array}$ & Qualitative / deep interview \\
\hline $\begin{array}{l}\text { Vosoogh } \\
\text { Moghadam A et } \\
\text { el. (2013) (23) }\end{array}$ & $\begin{array}{l}\text { Health in the } 5^{\text {th }} 5 \text {-years development plan of Iran: main challenges, general } \\
\text { policies and strategies }\end{array}$ & National report \\
\hline $\begin{array}{l}\text { Yazdi-Feyzabadi } \\
\text { V et al. (2011) } \\
\text { (12) }\end{array}$ & $\begin{array}{l}\text { Health information system in primary health care: the challenges and barri- } \\
\text { ers from local providers' perspective of an area in Iran }\end{array}$ & $\begin{array}{l}\text { Qualitative / semi-structured focus group dis- } \\
\text { cussions (FGDs) }\end{array}$ \\
\hline $\begin{array}{l}\text { Bagheri Lanka- } \\
\text { rani K et al. } \\
(2012-13)(24)\end{array}$ & Health in the Islamic republic of Iran, challenges and progresses & Debate article \\
\hline $\begin{array}{l}\text { Mehrdad R } \\
(2009)(25)\end{array}$ & Health system in Iran & - \\
\hline $\begin{array}{l}\text { Khalafi A et al. } \\
(2012)(26)\end{array}$ & $\begin{array}{l}\text { In field survey of attractions and repulsions of family medicine: family phy- } \\
\text { sicians' and medical students' attitudes }\end{array}$ & Cross-sectional / questionnaire (In Persian) \\
\hline $\begin{array}{l}\text { Asadi S (2013) } \\
(27)\end{array}$ & $\begin{array}{l}\text { Family physician assessment implementation based on the model (SWOT) } \\
\text { in Iran }\end{array}$ & Literature review (In Persian) \\
\hline $\begin{array}{l}\text { Mehrolhassani } \\
\text { M.H et al (2010) } \\
\text { (13) }\end{array}$ & $\begin{array}{l}\text { The challenges of implementing family physician and rural insurance poli- } \\
\text { cies in Kerman province, Iran: a qualitative study }\end{array}$ & $\begin{array}{l}\text { Semi-structured focus group discussions and } \\
\text { document reviews (In Persian) }\end{array}$ \\
\hline $\begin{array}{l}\text { Sedighi S (2012) } \\
(28)\end{array}$ & $\begin{array}{l}\text { The cause of resignation of physicians from rural family physician program } \\
\text { in } 2012\end{array}$ & Cross-sectional / questionnaire (In Persian) \\
\hline $\begin{array}{l}\text { Jabari A (2012- } \\
\text { 13) (29) }\end{array}$ & Overview of the performance of rural family physician in Iran & Review article (In Persian) \\
\hline $\begin{array}{l}\text { Mosa Farkhany E } \\
\text { et al (2012-13) } \\
\text { (30) }\end{array}$ & $\begin{array}{l}\text { Determining the causes of discontinuation of family physicians working in } \\
\text { Mashhad university of medical sciences }\end{array}$ & Cross-sectional / questionnaire (In Persian) \\
\hline $\begin{array}{l}\text { Damari B (2015) } \\
(31)\end{array}$ & $\begin{array}{l}\text { Challenges and directions of public health development in Iran from the } \\
\text { viewpoint of provincial health deputies and health center }\end{array}$ & $\begin{array}{l}\text { Interviews and focus group discussions (In Per- } \\
\text { sian) }\end{array}$ \\
\hline $\begin{array}{l}\text { Malekafzali H } \\
(2014)(32)\end{array}$ & Primary health care in Islamic Republic of Iran & (In Persian) \\
\hline $\begin{array}{l}\text { Javanbakht M } \\
\text { (2011) (33) }\end{array}$ & $\begin{array}{l}\text { Compare Comparative of Family Physicians system in Iran and other coun- } \\
\text { tries and investigating problems of Family Physician Program }\end{array}$ & Review and Comparative study (In Persian) \\
\hline $\begin{array}{l}\text { Jannati A et al } \\
(2009-10)(1)\end{array}$ & Assessing the strengths \& weaknesses of family physician program & $\begin{array}{c}\text { Descriptive cross-sectional / questionnaire (In } \\
\text { Persian) }\end{array}$ \\
\hline $\begin{array}{l}\text { Bayati A et al } \\
(2012-13)(2)\end{array}$ & $\begin{array}{l}\text { Factors influencing family physician program from the perspective of the } \\
\text { health team }\end{array}$ & $\begin{array}{l}\text { Phenomenological study / semi-structured in- } \\
\text { depth interviews (In Persian) }\end{array}$ \\
\hline $\begin{array}{l}\text { Mosaviraja S.A et } \\
\text { al (2009) (34) }\end{array}$ & $\begin{array}{l}\text { Influencing factors on family physician retaining in Kohgilooyeh and Boyer } \\
\text { Ahmad province, Iran in } 2009\end{array}$ & $\begin{array}{c}\text { Cross-sectional / questionnaire and interviews } \\
\text { (In Persian) }\end{array}$ \\
\hline
\end{tabular}

